\title{
Ethno-Tourism Research in Lovozero, Murmansk Region, Russia
}

\author{
Anna Aleksandrova ${ }^{1}$, Ekaterina Aigina $^{2}$ \\ 1,2 Department of Recreational Geography and Tourism, Faculty of Geography, Lomonosov Moscow \\ State University, 119991 Moscow, Russian Federation
}

\begin{abstract}
Ethno-tourism is one of the perspective ways for ethnic diversity conservation. Recent researches suggest that ethic and cultural tourism, very close in content, are fragmenting into a series of niches and start interacting with other types of tourism. Ethnic and cultural diversity of Russia give unique opportunities for development of ethnic and cultural tourism destinations in Russian regions. They are largely determined by the ethno-cultural potential of the region, its tourism infrastructure, as well as by position and activity of the native population and local authorities. The article presents the results of field-trip studies on ethno-tourism in Lovozero district in northern Russia where different ethnic groups face social, economic and ecological problems in the process of tourism development.
\end{abstract}

\section{Introduction}

Ethnic and national diversity is one of the hallmarks of the modern society. But the life of ethnic groups and minorities in context of globalization, rapid scientific and technological development, environmental crises, and increase of information flows is becoming apparently difficult. Ethnically based tourism is one of the options for ethnic diversity conservation.

Russia has exceptional resources for ethnic tourism development. Russian Federation is a home for more than 180 ethnic groups who represent various cultural, linguistic and religious communities. There are also more than 40 aboriginal peoples officially recognized by the state as "indigenous smallnumbered peoples of the North, Siberia and the Far East". In recent years specific ethnic tourism products have been created in more than 20 regions of northern and eastern Russia. Ethnic and cultural diversity of Russia and mutual historical influence of different cultures serve as important prerequisite for the growing interest towards this type of tourism.

Ethnic tourism represents one of the most promising opportunities for tourism development in Russian regions because of its unique and diverse content and, in particular, because of the chance for tourist to become an active participant of authentic cultural life. The increasing interest in indigenous culture, objects and ethnic phenomena, their everyday life, costumes, language, folklore, traditions and customs, ethnic creativity caused the rise of indigenous tourism. 
But there were no generally accepted and stable definitions and understanding of ethnic and cultural tourism in professional tourism literature in Russia. As a result, its possibilities haven't been appreciated by the tourism industry at full scale yet.

\section{Ethnic and Cultural Tourism}

The term "ethno-tourism" had been rarely used in Russian tourism studies up to the beginning of the 21 st century. First it was interpreted as trips to the places of residence of small aboriginal peoples who had no national or administrative entity within the Russian Federation. In this context, the traveler's interest towards the variety of ethnic and cultural display within Russia was artificially reduced to the only form of ethnic or ethnographic tourism - to aboriginal or indigenous tourism - aimed at familiarizing with the culture of ethnic groups leading traditional or tribal life in their communities. With such a narrow interpretation of ethno-tourism vast majority of small peoples of Russia simply dropped out of the range of objects for tourism visits.

In modern understanding this type of tourism is regarded as an umbrella notion. Ethnic and cultural tourism (or ethno-cultural tourism) is considered to be a combination of different forms of tourism activities caused by the desire for understanding of manifold phenomena in ethnic and cultural spheres [1]. There is a need to recognize ethno-cultural tourism as an independent and integrated type of tourism. This is indicated by the specificity of tourism resources used in its framework, by different motivation of tourists and particular requirements for its personnel and management.

Cultural tourism (this term is now widely used in many countries) provides introduction to the country's history and culture in all its aspects, including architecture, painting, music, theater, folk traditions and way of living. But as culture itself is a very broad notion, this type of tourism also covers various kinds of activities, forms of art, historical periods (contemporary culture including) and nations, etc.

This definition is largely identical to the definition of ethnic tourism, which means traveling with the purpose to experience ethnic or national heritage - traditional forms of nature use, traditional ways of living, customs, language, food, settlements, folklore, and other elements of traditional national culture. So, the diversity of ethnicity and culture makes it difficult to give strict definitions and to distinguish these types of tourism. Both cultural and ethnic tourism deal with national culture but are now fragmenting into a series of niches [2].

Now it is proposed to distinguish particular subtypes of ethno-tourism, such as ethnographic tourism, nostalgic tourism, ethno- and ecotourism, ethno-educational tourism, anthropological tourism, religious tourism, etc. [1,3,4]. For example, ethnographic tourism is based on special interest in culture of a certain ethnic group (people or nation), ethnic items and phenomena, everyday life, costume, language, folklore, customs and traditions, ethnic creativity, etc. Nostalgic tourism involves tourists visiting their ancestral homeland to get acquainted with cultural heritage of their original nation.

The combination of ethnic and ecotourism seem quite important as their common purpose is to make tourists acquainted with traditional livelihood and natural environment of particular nations. This type of tourism is also very close to aboriginal, or indigenous, tourism in its traditional meaning. It usually appears in places of traditional residence and traditional economic activities of indigenous peoples and acts as important tool for their traditional economy development. Active involvement of indigenous people in all types of tourism activities within indigenous tourism provides stable and systematic development of their traditional culture and economy [5].

In last decades the space between ethnic and ecological tourism was also filled by rural tourism (agritourism). Its specific features come from the fact that tourists stay in settlements with traditional folk lifestyle, live the usual rural way of living. Modern tourists find rural culture very attractive, authentic and even exotic. 
Other interaction - between ethnic and educational tourism - has a distinct sightseeing and edifying character, which become evident when tourists visit ethnographic, historical and cultural sites (museums, historical settlements, ethnographic open-air museums, etc.). Some ethnic tourism products may have strong religious orientation; in that case, in addition to traditional way of living and national customs, tourists are introduced to religious beliefs and traditional behavior of some ethnic groups. In case of combining "pure" ethnic and religious tourism at first tourists immerse in the corresponding ethno-cultural environment and only then visit sacred sites and/or carry out religious practices. Sometimes introduction of tourists to religious beliefs come through their knowledge of ethnic culture.

Quite frequently we can see a combination of ethnic tourism and adventure or active tourism. Along with the visits to national settlements to get acquainted with traditional culture tourists carry out different sports activities, such as rafting and hiking, rock-climbing, horse-riding or water sports on lakes and rivers, etc. Other combinations are also possible.

In fact, the analysis of tourism supply presented by the companies involved in ethno-tourism shows clearly that the variety of submitted tourism products and individual programs is much broader than its definition; and, what is more important, this type of tourism contributes not only in material but also in more subtle, cultural way.

\section{Ethno-Tourism in Russia}

The growing interest of tourists to different nations and their traditional culture has become a global trend within the context of increasing globalization, urbanization and total unification. According to many experts, traveling with ethno-cultural motivation will develop into one of the most dynamic forms of international tourism in the second quarter of the 21 st century. Ethnic and cultural factors determine essentially the rate of tourist interest towards various destinations.

The main reason for ethno-tourism development in Russia is a high degree of its population ethnic diversity, which is manifested not only on national or regional scale, but also within individual subjects of Russian Federation, and even inside local administrative units (districts, municipalities, rural communities). Russia has traditionally been perceived as a country with great cultural and historical heritage and high ethnic diversity. There is a unique combination of different ethnic and cultural complexes, primarily East Slavic, Turkic and Finno-Ugric, that had developed during the long period of ethnic integration, acculturation and assimilation in Volga region (Tatar, Bashkir and other Volga republics) and in the Urals, as well as in the Southern Siberia (Tuva, Buryatia and other regions) and in the Russian Arctic. Ethno-tourism can be used as a tool for more effective promotion of domestic and inbound tourism in other regions of Russia; for example, in the far-away regions with low rate of tourism interest.

Quite often the most interesting ethnic groups live in the most distant parts of the country with no roads and no hotels. But even if there are any, tourist visits are possible only for a few months a year. Ethno-tourism development depends on several factors: tourism potential of the region, ethnic community and local authorities' attitude towards tourism, availability of necessary infrastructure and competent personnel.

The positive results are evident if these factors come together. Yamal-Nenets and Khanty-Mansisk areas in Tyumen region (Western Siberia), Krasnodar and Stavropol regions (Northern Caucasus) can be regarded as the most advanced in terms of ethno-tourism in Russia. But most of Russian regions just start to move in this direction.

The list of existing or emerging centers with more or less successful development of domestic ethno-cultural tourism includes at least a dozen destinations. In particular, there are famous ethnographic programs for tourists in Vologda and Arkhangelsk regions and in the Baikal area. The Republic of Karelia and Kaliningrad region are widely known for their nostalgic tours. 
Ethnic and ecotourism tours in Kamchatka and Khabarovsk regions have become world-famous. Indigenous tourism programs have already appeared in the Republic of Altai and Buryatia. With adequate investments and effective work of tourism companies and their partners ethno-tourism can become a priority for both inbound and domestic tourism in many other regions of Russian. Ethnic villages, multifunctional complexes with hotels, catering and ethnic leisure venues, as well as farmhouses, open-air ethnographic museums are now arranged in Orenburg and Rostov regions, Krasnodar region, Republic of Komi and many others, including places of indigenous peoples residence in the north of Yamal peninsula, in the Khanty-Mansisk autonomous area, Yakutia, etc.

Ethnic idea is not new for Russian tourism. For example, "Torum Maa" ethnographic museum in Khanty-Mansisk was founded in 1987 and today is very popular, both among locals and visitors. Native Village of the Russian North "Pozharische" in Nyuksenitsa, Vologda Region has been visited by more than 20 thousand tourists in 3 years and was recognized as the best regional tourism project in 2009. According to Russian Federal Agency for Tourism public opinion survey $88 \%$ of respondents are ready to try ethno-tourism products. But $91 \%$ of them mentioned that there isn't enough information (primarily ethnographic guides) and promotional materials on this topic [6].

\section{Area and Methods of Study}

In January-February 2009 a group of researchers and students representing Department of Recreational Geography and Tourism, Faculty of Geography, Lomonosov Moscow State University held field studies on ethno-tourism development in Lovozero district, Murmansk region. The field-trip was aimed at understanding the possibilities for sustainable ethno-tourism development of this area. Murmansk region is the only region of European Russia where aboriginal people - the Sami - still live. They are the only indigenous people of Scandinavia (Sami also live in Norway, Sweden and Finland) and northern Russia recognized and protected under national and international conventions of indigenous peoples.

Lovozero administrative district covers central and eastern parts of the Kola Peninsula with the territory of 53 thousand $\mathrm{km}^{2}$ (36.9\% of the Murmansk region) and the population 11.8 thousand $(1.5 \%)$. So, the population density in this area is the lowest among all other parts of the region. According to the 2010 Census 1599 Sami (90\% of all Sami in Russia) live in Murmansk region, mainly in Lovozero district [7]. There are five settlements in the district: Revda (an industrial settlement with mainly Russian population) and 4 villages: Lovozero, Krasnoschelje, Kanevka and Sosnovka. Lovozero is the largest Sami settlement in Russia. According to the estimates, about 660680 persons or $23-25 \%$ of its population are Sami.

The study was based on descriptive and analytical approaches. Participant observation and primary data collection were used as the main field research methods. They included collecting qualitative data through passive observation and informal interviews as well as active participation in various activities suggested by the members of Sami community. Cultural presentation including annual Izhma Komi festival was followed by a day snowmobile trip to Sami sacred sites. A number of indepth interviews with the representatives of local tourism industry, with the members of Sami and Komi communities and local residents provided the researchers with realistic information about tourism possibilities and economic situation in Lovozero district and broad-spectrum attitude towards ethno-tourism development in the area. The data obtained during field research was supplemented with theoretical and statistical background afterwards.

\section{Ethno-Tourism Resources in Lovozero Area}

Lovozero Tundra is located in the north of European Russia, above the Arctic Circle. It is a separate rocky area rising above northern forests between the Lovozero and Umbozero lakes. Inside the mountains there is Seidozero Lake located in a stone bowl with steep walls. The area is extremely 
interesting from geomorphologic and geologic points of view. The rocks are rich in rare earth metals which are mined here.

This area has a specific climate, significantly different from the climate of neighboring low areas and valleys because of extremely unstable weather with long and harsh winter and short cold summer, high humidity and precipitation (about $1000 \mathrm{~mm}$ per year) and strong winds. Severe weather conditions in Lovozero Tundra make this area extremely unpredictable and dangerous for organization of tourism routes.

But the unique natural resources of Lovozero Tundra give fantastic opportunities for different types of tourism, such as ecotourism, various forms of active, adventure and extreme tourism, including rock climbing, cross-country and mountain skiing, sport hunting and fishing, trophy rallies and others. In 1982 the State Natural Reserve "Seidyavvr" was organized here in order to protect natural habitat and traditional indigenous culture, to preserve Sami places of worship, to provide sustainable economic development and conservation of natural resources.

Sami is the only ethnic group of European Russia included in the state list of "indigenous smallnumbered peoples of the Russian North, Siberia and the Far East". These are nations with less than 50 thousand people living in the northern regions of European Russia, Siberia and the Russian Far East in the areas of their ancestors' traditional settlements, preserving traditional way of life, trade and crafts, and considering themselves as separate ethnic groups. This status gives a number of social, political and economic benefits and governmental support if compared with other local ethnic groups.

Kola Sami did not live here alone. They had close contacts with other peoples; first of all, with the Russians, who came to this area eight hundred years ago from Novgorod the Great. This ethnic group, called "pomory", had numerous settlements along the White Sea coasts. Their traditional livelihood was based mainly on hunting, fishing and whaling. In addition to Russian settlements in the Sami area Karelians and Finns used to live mainly in the south-west of the peninsula, as well as Izhma Komi and Nenets - mainly in the eastern regions. It is interesting to mention that Izhma Komi and Nenets moved to the Kola Peninsula with their reindeer herds in 1887 from Pechora region over the White Sea ice because of heavy diseases that caused massive loss of deer. So, this area has not only indigenous but also "alien" ethnic communities with their traditional culture and way of living. In addition, Izhma Komi representatives are currently seeking recognition as a distinct indigenous people of the North to improve their position.

The population of Lovozero district now is gradually decreasing due to the low level of its economic and social development. Sami face problems common to many indigenous peoples in all parts of the world. According to interviews conducted by students in course of field studies, many people do not connect their future with this region. The amount of rare earth metals produced here is declining; there are no opportunities for agriculture; traditional reindeer herding is also in crisis, the ecological situation is deteriorating. There are serious problems in providing necessary health care and primary education; transport infrastructure is scarce. There are no roads to Krasnoschelje, Kanevka and Sosnovka, and these villages can be reached only by airplanes or by snowmobiles in winter. In such circumstances it is too early to speak about tourism development in the area.

However, Lovozero district has great natural, historical and cultural resources for tourism. The uniqueness of the Sami and Komi people culture and the exceptional natural and cultural resources attract well-informed and experienced tourists even now. There are some tourist flows in the area, but they are mostly unorganized ("wild") tourists. In order to create tourism industry it is compulsory to build infrastructure that corresponds to generally accepted quality standards and to develop tourism products required by visitors. But it is also important to keep away from commercialization of indigenous heritage and authentic environment of the local culture [8].

\section{Problems and Solutions}

The accessible resources allow to form a variety of regional tourism products, such as salmon fishing, ski tours, rock climbing, extreme rallies, boating and rafting on rivers and lakes, mineralogical tours, hunting trips; ecological, adventure, historical and ethnographic tours and excursions intended for 
different types of tourists. But in order to attract tourists in this particular area all tourism products have to contain some ethnic components of the local indigenous culture; they should be "marked" by it. Regional tourism products can be arranged on the basis of traditional ethnic knowledge of indigenous peoples, such as:

- Association with local nature and landscapes;

- Experience in reindeer herds life;

- Nomadic techniques and vehicles;

- Traditional skills of camping, nomadic dwelling and living;

- National food and customary ways of cooking;

- Habitual clothes and materials;

- Traditional national calendar and events;

- Traditional medicine;

- Long-established socio-cultural ties, values, stereotypes of personal and public relations, etc.

For example, tourists can visit places of traditional reindeer herding and watch the life of wild animals. They can also take part in reindeer races, dressed in "malitsa" - traditional warm clothing made of reindeer fur, buy traditional souvenirs made of deer antlers and try jerked deer meat. But, in fact, these traditional activities can be hardly found now as there are not many reindeer in the area. Now, a few deer can be seen only during Sami holidays or in isolated pastures with difficult access. Consequently, protection and development of traditional activities becomes one of the priorities for ethno-tourism in the region.

Fishing has always been traditional for the Sami and other peoples. But in the past 15-20 years it became terribly confronted with the interests of tourism companies providing sport fishery tours for freshwater fish and salmon in the Kola Peninsula. Salmon fly fishing, which is particularly popular among American and European tourists, takes place mostly on traditional Sami lands, and local residents are often unable to get there and follow their usual activities. Moreover, their experience and knowledge and, as a result, their participation, are not required. The lack of interaction between alien tourism companies and the local population is a very important problem in the region.

The harsh climate, complicated landscape and the absence of people give opportunities for the extreme tourism which is becoming popular among tourists from big cities of Russia. Snowmobile routes are particularly attractive in winter; in summer there are trips for off-road vehicles. But even these activities include ethnic components: for example, routes to the most famous, including sacred, ethnic sites, traditional food, legends and customs of the local people, etc.

Tourists can see many unusual objects and events associated with the Sami culture in the neighborhood of Lovozero. They have the chance to listen to unusual Sami overtone singing and chat with northern shaman. Local History Museum presents interesting exhibitions on the Sami history, creativity and spiritual ceremonies. The most interesting presentation of national culture can be seen during national holidays and events. Every year in March Lovozero hosts traditional "Feast of the North", where local people and tourists can see and participate in various competitions, such as reindeer races, reindeer skijoring, cross-country skiing, Sami soccer, etc. The World Sami Games attract visitors from different parts of the Murmansk region and Scandinavia every year in June. National holidays, crafts and folklore make regional tourism product more attractive and vivid.

Like all the native peoples, Sami believe in nature and have many sacred natural sites. These sacred stones and rock engravings are usually located in traditional places for hunting and fishing and are clearly visible far away. In the process of tourism development many of these places were discovered by tourists and, according to the Sami, desecrated. Conflicts between tourists and Sami become very sensitive, and representatives of the Sami community believe that it is necessary to close completely some parts of the mountains and lakes for tourists. On the one hand, from ecotourism point of view the limitation of the number of tourists to the unspoiled natural areas will help to preserve 
them. On the other hand, the local people believe that all the decisions on the future of tourism places should be taken only by the local Sami. Such position holds back tourism development in the area.

In other Scandinavian countries, where Sami live, the situation is very much alike. Tourism development is accepted but it is believed that the use of Sami places and symbols should be controlled by the Sami, and both the tourism industry and the tourists should act respectfully [8].

The study of tourism development in the Sami areas in Russia and Scandinavian countries shows that ethnic component can be clearly seen in all types of tourism [9]. Traditions and culture of indigenous peoples living in the region act as the most attractive factor for tourism development in the area. It has already been understood by the regional state authorities. The law "On State Support to Tourism Development in the Murmansk Region" adopted in 2008 provides the organization of special tourism areas in different parts of the region [10]. It is planned to arrange one of these tourism areas in Lovozero as it has huge tourism opportunities. With the Sami village and Sami cultural center in its core, this tourism area can have distinct ethnic character as the key feature of regional tourism.

About 20 travel companies offer various types of tours to Lovozero now. Many of them suggest traditional lifestyle experience while staying in indigenous peoples' families, traditional way of living, national dishes and dwellings. It is interesting to mention that sometimes tourists do not know that they are offered pieces of Komi traditional culture (which is well preserved in the villages), not Sami. Foreign tourists consider some elements of traditional Russian culture as local and indigenous.

But new projects on ethno-tourism appear in this area as well. For example, there is an idea of reconstruction of Chalmny-Varre village abandoned by its residents in 1960s. It is planned to restore the old settlement and to build a comfortable lodge in traditional Sami and Komi national style to invite tourists for fishing, hunting, ecotourism and other types of tourism activities all year round. Famous old rock engravings in the nearby act as a "bait" for investors as they help to construct the image of tourism attraction with natural and cultural sites associated with the pagan culture of indigenous peoples.

\section{Conclusion}

Tourism is one of the most important elements of environmental management that can ensure successful development of the region. It brings revenues, stimulates nature conservation, and creates new jobs that are attractive to local population, young people and women, in particular. Ethno-tourism is the part of tourism industry which involves indigenous population whose ethnic individuality becomes major tourism attraction. In other words, ethnic and cultural characteristics of local population, sustainable use of regional resources are the core of ethno-tourism.

Ethno-tourism helps visitors to realize their individual interest in new cultural and authentic experience by active participation in traditional way of living, handicrafts, events, folklore (preserved, reconstructed or modern). The opportunity of staying with a local family, sharing traditional activities of the local population and their traditional way of living make the tourist product in various types of tourism more impressive and different.

The indigenous nations of Lovozero area see tourism as the chance for economic and cultural development of their territory but they are watching this process with vigilance as tourism can bring losses to their authentic culture and national identity. The main task now is to explain the local population that normal tourism development can bring big profits comparable to mining, metallurgy, trade or reindeer herding, but with less damage to the environment. Using the experience of similar areas in the Nordic countries, Lovozero may become prosperous and save its natural and cultural uniqueness.

\section{References}

1. A.G.Butuzov, Ethnocultural Tourism, KNORUS Publishers (in Russian) 82-110 (2013)

2. G. Richards, New directions for cultural tourism? UNWTO Tourism Market Trends137-148 (2004) 
3. M.D.Suschinskaya, Cultural Tourism: a Textbook, Saint-Petersburg University Publishers (in Russian) 37-57(2010)

4. T.Yu.Tikhonova, Ethnic Tourism in Regional Development (2012) URL:http://www.rusnauka.com/17_AVSN_2012/Geographia/1_112134.doc.htm (in Russian).

5. R.Butler, T.Hinch (editors) Tourism and Indigenous Peoples: Issues and Implications, Elsevier Ltd.1-2 (2007)

6. RATA-News, daily electronic newspaper of the Russian Travel Industry Union URL:http://ratanews.ru/news/news_6052011_1.stm (in Russian)

7. 2010 Population Census in Russian Federation. Results presented by State Statistics Commitee of Russia, URL:http://www.gks.ru/free_doc/new_site/perepis2010/croc/perepis_itogi1612.htm

8. R.Pettersson, A.Viken Sami perspectives on indigenous tourism in northern Europe: commerce or cultural development? - Tourism and Indigenous Peoples: Issues and Implications, Elsevier Ltd. (2007)

9. S. Blangy, Le Guide Des Destinations Indigènes, Collection Indigène Esprit (2006)

10. The law "On State Support to Tourism Development in the Murmansk Region" N 949-01-ZMO adopted on 09.04.2008 (in Russian) (2008) 